\title{
A.JOTE
}

African Journal of Teacher Education

ISSN 1916-7822. A Journal of Spread Corporation

Volume 10. No. 12021 Pages 87-105

\section{Modelling in Teacher Education: Beliefs of Teacher Educators in Rwanda}

\author{
${ }^{1}$ Emmanuel Niyibizi \\ Centre for Didactics and Research in Education (CEDRE) \\ Protestant Institute of Arts and Social Sciences (PIASS) \\ Rwanda \\ https://orcid.org/0000-0002-5723-7688
}

\begin{abstract}
The study aims to explore teacher educators' beliefs about role modelling in teacher education in Rwanda. This study hopes to contribute to filling the gap created by limited empirical study available on teacher educators and the relevance of role modelling for high quality teacher training. The study was designed as an exploratory qualitative research using semi-structured interviews of 20 purposively and conveniently selected teacher educators. Content analysis was used to analyze collected data. The findings reveal that participating teacher educators believe that role modelling is an important component in the process of teaching teachers. Moreover, participants hold beliefs about role modelling as implicit exemplar practices and behavior. They think that teaching teachers involves not only providing knowledge but also serving as a good example in both teaching practices and behavior at training institutions as well as in the society. The study concludes that both implicit and explicit modelling should be included in the overall reflections of policy, research and practice of pedagogy of teacher education and especially in the professional development of teacher educators. Further empirical studies are recommended about the implications of implicit modelling on student teachers' learning outcomes.
\end{abstract}

Key words: Role modelling, teacher education, student teacher, teacher educator, beliefs

\section{Introduction}

Beliefs are at the heart of human endeavors. In the context of education, delineating beliefs of teachers and teacher educators is an important step for further reflections about educational 
improvement. This study explored teacher educators' beliefs about modelling in teacher education in Rwanda. The study was undertaken within the framework of the international educational discourse of educational quality as worldwide concern. Education quality is at the heart of achieving the Sustainable Development Goals (SDGs) (UNESCO, 2017). Without disregarding other factors, quality teachers and teaching remain at the forefront of educational quality (World Bank [WB], 2018; UNESCO, 2015; 2014; 2004; Hattie, 2012). The quality of a teacher is largely dependent of the quality of teacher education imparted by teacher educators (Nilsen, Gustafsson \& Blömeke, 2016; Vavrus et al., 2011; Baumert \& Kunter, 2013) through their intervention in teacher professional development both pre- and in-service (European Commission, 2017:4). Moreover, teachers' and teacher educators' beliefs largely influence teachers' decisions and behaviours concerning teaching practice (Martinez, Castro, Vystrcilova \& Magliacci, 2017; Voss, Kleickmann, Kunter \& Hachfeld, 2013). In this framework, teacher educators' beliefs about teacher education are expected to significantly influence the quality of the whole education system. Unfortunately, empirical research on teacher educators' professionalism, thinking and practice is limited worldwide (European Commission, 2017) and particularly in the Global South.

The aphorism stating that "teachers teach as they are taught, not what they were taught to teach" (Vavrus et al, 2011 \& Blume, 1971), is a demonstration of the reality that exemplary practice (modelling) by teacher educators is seen as the most important component to engineering the quality of teacher education (Loughran, 2006:39). Some researchers in the field of teacher education, mostly from the Global North, show that modelling, especially explicit modelling, is a tool for challenging and even changing previous experiences which might have been taken as habitus and may hinder learning to teach (Lunenberg, Korthagen \& Swennen, 2007; Loughran, 2006; Russell \& McPherson, 2001). Unfortunately, empirical studies on how teacher educators conceptualize modelling is quite limited in the empirical global educational discourse.

In line with the $21^{\text {st }}$ century international political discourse on education, Rwanda registered significant quantitative progress of access to education at all levels (MINEDUC, 2020). However, educational quality remains an issue of high concern (MINEDUC, 2018). Despite increased quantitative qualification of teachers (MINEDUC, 2020) and other investments in educator sector, learning outcomes are still alarmingly poor (HEC, 2015 \& World Bank, 2011). At the level of pedagogy, the government advocates and recommends competence- and learner-oriented teaching as a form of quality teaching (MINEDUC/REB, $2019 \& 2015$ ). However, a policy-practice gap 
persists. Teacher and content- dominated teaching practices are still a reality in the Rwandan education system, including at teacher education institutions (Otara, Uworwabayeho, Nzabalirwa \& Kayisenga \& 2019; Kuilen, Altinyelken Voogt \& Nzabalirwa, 2019, Iwakuni, 2017, MINEDUC, 2018; Sibomana, 2014; Mugisha, 2010). The status of teacher educators is largely unrecognized in education policy formulation. They are trained either as general teachers for nursery or primary school levels or as subject teachers for secondary schools or subject specialists without training about teacher education. Even then, empirical research in Rwanda on teacher educators' professionalism, thinking and work is sparse.

\section{Modelling: Theoretical and empirical framework}

Modelling in teacher education is rooted in social cognitive theory as developed by Albert Bandura (1986). In this theory, Bandura emphasizes the role of observational learning whereby students learn from experts who modelled a desired behavior and/or skill. In the context of teacher education, observation is seen as a teaching strategy where student teachers learn from teacher educators (Chernikova, 2018:24). On the one hand, teaching through modelling is appreciated for helping what cannot only be learnt in content-independent teaching (p. 14). Teaching through modelling was reproached as having a number of drawbacks. First, students may observe and them imitate bad behaviors and/or skills. Second, observed behavior does not always lead to change, especially because the observer does not know the thinking behind the behaviour (Bandura, 1971 $\&$ 2001). Moreover, teaching through observation may lead to cognitive bias especially when learners choose what might keep them in their comfort zones (Bandura, 1986). To make teaching through observation more beneficial to students, explicit constructive feedback is a necessity to foreclose students' misinterpretations (Chernikova, 2018:45). In the context of teacher education, post-observations reflections should be used to facilitate student teachers benefiting from what they observed for use in their future career.

Conceptualized as demonstration of exemplary practice, modelling is an important tool for quality teacher education (Loughran, 2006:39). Some scholars have argued that teaching prospective teachers is not only about pedagogical contents but also how the latter is conveyed to students. Whether good or bad, intentional, or unintentional, how teaching is portrayed plays a significant role for training teachers (Lunenberg, Dengerink \& Korthagen, 2014; Lunenberg, 
Korthagen \& Swennen, 2007; Korthagen, Loughran \& Russell, 2006 \& Loughran \& Berry, 2005). This implies that teacher educators should take care of how they teach student teachers.

There are two types of modelling, implicit and explicit, in the context of teacher education (Lunenberg, Korthagen \& Swennen, 2007). First, teacher educators implicitly serve as role models in terms of teaching practice. This is implicit because student teachers do not know the reasoning behind teachers educators' choices and practices. Though student teachers may learn from this form of modelling, research has shown that it is not sufficient and may be ineffective. Researchers advocate for explicit reflection of teacher educators' practice in order to understand the pedagogical reasoning, thoughts, choices and actions behind. They advocate for submitting teacher educators' teaching practices to critique and interrogation in a form of meta-commentary (Philpott, 2014; Lunenberg, Korthagen \& Swennen, 2007; Loughran, 2006 \& 1996; Loughran \& Berry, 2002). A survey of extant literature on teacher education shows that implicit modelling is less reflected and is neglected. The tendency is to overvalue the explicit as the favored form of modelling in teacher education.

Five forms of explicit modelling (see Model 1) are described. First, explicit modelling is done through a process of thinking aloud, which according to Loughran (1996), consists of explaining to student teachers the pedagogical choices before any teaching session. The same author shows that this form, though confusing, is helpful for prospective teachers especially developing the culture of reflecting the pedagogical choices for their teaching. The second also by Loughran (1996) is journal writing. This consists of regularly keeping a journal which synthetizes the pedagogical choices of teaching practices. The journal is made available for students of teaching who later read it to understand the teacher educator's reasoning behind a practice. This used a delayed reflection since it is mostly made available to students later after teaching. Research on how it is used and its effects on learning to teach is still unavailable. The third form of modeling is co-teaching. This is done by two teacher educators where one models (teaches) and is followed by a debriefing by the other. Practices and underlying assumptions are discussed in the plenary (Loughran \& Berry, 2002). Fourth, modelling is done by involving student teachers in the process of reflecting the relevance to their prospective teaching practice (Loughran, 1997). Teaching practices, though discussed with student teachers, should not be copied blindly. Rather student teachers must reflect on their teaching practices to render them useful to their future teaching practices (Lunenberg, Korthagen \& Swennen, 2007: 591). The last form of modelling involves 
explaining the theory underlying the practices (Munby, Russell \& Martin, 2001). This means that the teacher educator explains the relationship between her/his teaching practice and theory. The following model summarizes forms of modelling in teacher education.

Model 1: Types of modelling in teacher education

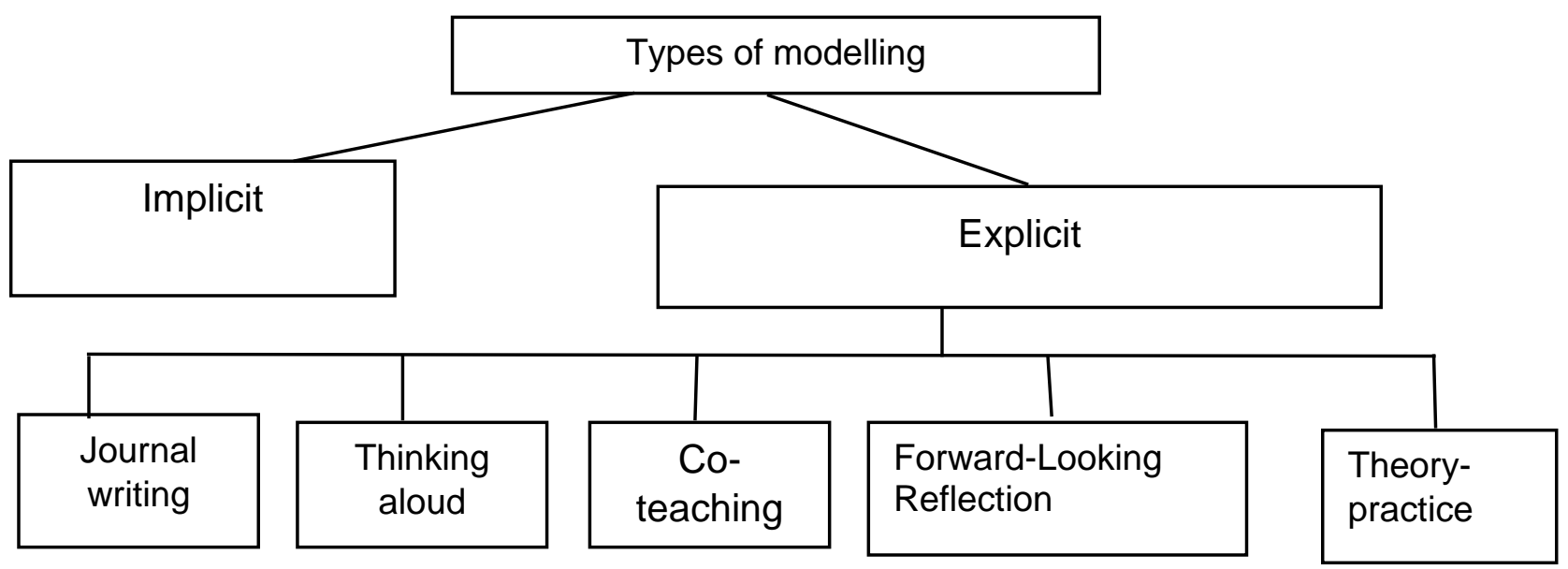

Source: Adapted from Lunenberg, Korthagen \& Swennen, 2007; Loughran, 2006; Loughran \& Berry, 2005 \& 2002, Munby, Russell \& Martin, 2001.

Explicit modelling is related to a reflective practice which is important for teacher education and specifically for both student teachers and teacher educators (Mathew, Mathew, \& Peechattu, 2017 \& Lane, McMaster, Adnum \& Michael Cavanagh, 2014:482). On the one hand, it enables student teachers to understand the complexity of teaching through having access to and discussing, questioning, and reflecting on teacher educators' reasoning behind their practices. On the other hand, implicitly, student teachers would learn to adopt reflective practice in their prospective practices. Additionally, explicit modelling can also contribute to the improvement of teacher educators' reflections and practices (Philpott, 2014; Korthagen, Kessels, Koster, Lagerwerf \& Wubbels, 2001\& Loughran, 1996). Explicit modelling may contribute to enlarging teacher educators' pedagogical repertoire, help them to progressively reflect on their own practices as well as the relationship between theory and practice. In this framework, explicit modelling may be a dynamic and transformative tool of teacher education (Lunenberg et al., 2007:589). Though explicit modelling is praised in extant research, it does not mean that it is common for all teacher educators. This leads to the question, how does modelling look like in the global south, and particularly in Rwanda? 


\section{Research question}

Given the proven importance of modelling in improving the quality of teacher and the paucity of empirical research on teacher educators (Swennen \& White, 2021; Vavrus et al., 2011 \& VillegasReimers, 2003), especially their beliefs of role modelling; the study at hand seeks to answer the following question: How do teacher educators in Rwanda understand modelling and its role in teacher education?

\section{Research methodology}

As indicated earlier (1), empirical research on the topic in terms of participants and content is limited. Hence, I adopted an exploratory qualitative research design (Savin-Baden \& Major, 2013 \& Creswell, 2014). This design seems to be adequate (cf. Silverman, 2014 \& McMillan \& Schumacher, 2014) as it facilitates self-verbalizing beliefs of teacher educators about modelling. Using purposive and convenience sampling strategies (Thornbeg \& Charmaz, 2014:156), data was collected from 20 teacher educators. For confidentiality and anonymization, participants were given names of football teams in Rwanda. ${ }^{1}$ The sample is composed of $45 \%$ and $55 \%$ males and females respectively with qualifications ranging from undergraduate to $\mathrm{PhD}$ (Undergraduate: 70\%, Master, 25\% and $\mathrm{PhD}: 10 \%$ ). By way of professional experience, $80 \%$ have taught in general education before joining teacher training, $25 \%$ have taught for less than five years, 50\% for 5-6 years, and $25 \%$ for more than 11 years. By way of in-service training, all participants have participated in general pedagogical training, $40 \%$ attended subject-related training, and $20 \%$ in subject didactics training. The profile of participants shows that no one has participated in a specific training on teacher professionalization.

As beliefs are related to personal interpretations of reality and experiences (Hansen, 2000 \& Martinez et al., 2017), the semi-structured interview was used as a method of data collection. The use of pre-set questions and the flexibility of asking more questions to get rich information through semi-structured interviews gave the researcher an opportunity to clarify and deepen what the interviewee said (Mason, 2018; Savin-Baden \& Major, 2013). Collected data was analysed with content analysis (cf. Mayring, 2014) using MAXQDA, which enabled the researcher to identify the emerging themes in relation to the research question.

\footnotetext{
${ }^{1}$ Names of football teams in Rwanda: Army, Espoir, Gasogi, Gicumbi, Isonga, Jeunesse, Kibuye, Kigali, Kirehe, Kiyovu, Magaju, Marine, Muhanga, Mukura, Musanze, Panthère, Police, Rayon, Sunrise, Zebra.
} 


\section{Findings}

Working from a framework of teacher educators' beliefs about modelling in Rwandan teacher education, the study systematically describes themes identified during the analysis of interview transcripts. First, findings about the meaning of modelling as well as its role in teacher education are presented. Second, I describe the typology of beliefs about modelling that emerged from interviewees' transcripts.

\subsection{Awareness of teacher educators about modelling}

It is observed from interviews that participants are aware of modelling and its importance in teacher education. For example, Kigali indicated:

... you not only teach what you know but also who you are. How s/he is seen by student teachers, they can imitate if what her/his teaching is good or how s/he behaves, they may imitate and do their work effectively later..." (74-76).

This implies that the how of teaching teachers is important in getting student teachers inspired for their future teaching practice. For this to be possible, teacher educator's practices should not contradict what they say (Jeunesse:71-72). Moreover, participants are aware that student teachers are likely to apply teaching methodology they had experienced in initial teacher education. Kigali expressed this as follows:

“...you see most of the time we teach as we were taught. If someone experienced quality teaching using effective teaching methodology, using methodology that facilitates freedom of expression of opinions, and this is promising that the student teacher will use the same teaching methodology s/he experienced during her/his learning. I am not sure if it can 100\% but there is a high probability that s/he can use it s/he already has a reference..." (Kigali:7984).

Though Jeunesse believes that student teachers should implicitly learn from teacher educators' teaching practices, (73-75), Isonga shows that sometimes student teachers may take for granted what they observed from teacher educators, whether wrong or right (213-214).

The results from interviewees show that participants are aware of modelling and believe that teacher educators should take care of both the what and how of the training process of 
prospective teachers. The question which may arise is what types of modelling participants believe may facilitate this process.

\subsection{Typology of teacher educators' beliefs about modelling in Rwanda}

The analysis of interviewees' transcripts reveals one type of modelling: Implicit exemplar practice and behaviour (Model 2). This refers to teacher educators serving as role model both in teaching and behavior (inside and outside school context). This remains hidden to students because it is not reflected during or after teaching sessions.

\section{Model 2: Typology of teacher educators' beliefs about modelling in Rwanda}

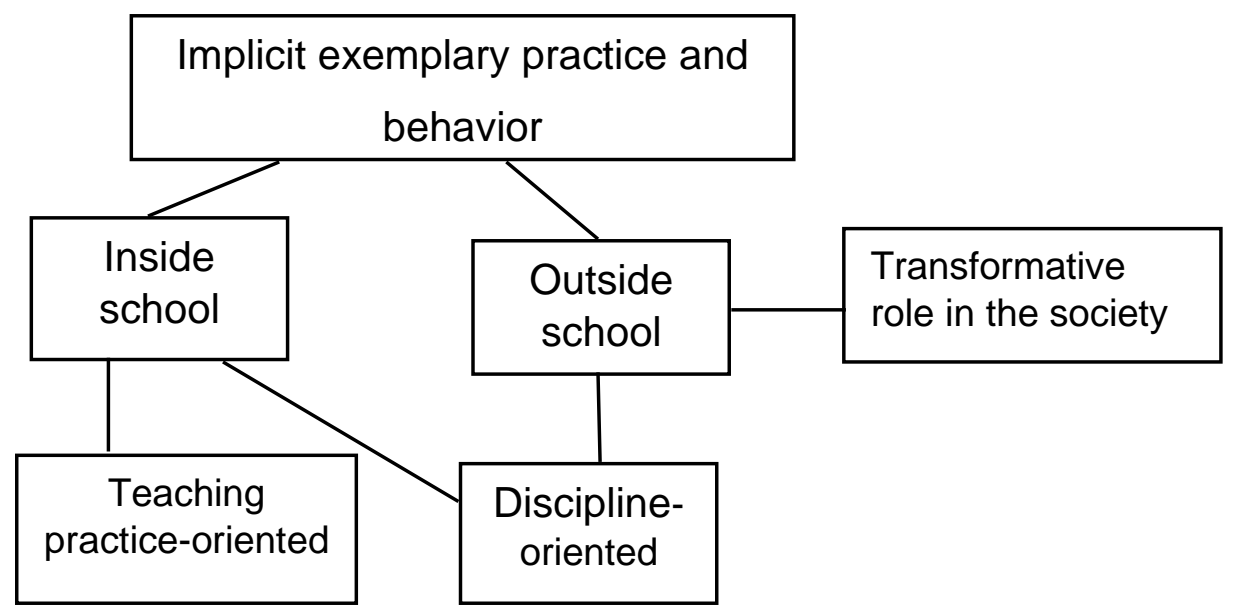

Source: Primary data (2020)

\subsubsection{Implicit teaching exemplar practice}

In the views of interviewees in this study as emerged from transcripts, fulfilling preparatory formalities and pedagogical practices are two ways of role modelling. The first consists of regularity in completing administratively pedagogical documents. The second is related to modeling practices showing a mastery of content, and strictly follow parts of a lesson, use of learner-centered methods, classroom management especially students with learning difficulties where they should be provided with extra-support.

Modelling through implicit fulfilment of preparatory formalities 
Compliance with formalities in terms of pedagogical preparation is seen as a way of role modelling by teacher educators who participated in this study. One interviewee expressed this as follows:

"...first of all you should have those documents, those documents which guide the teacher. The first document is called lesson plan, there is a scheme of work, there is a class diary, there is a so-called recording of marks. It is like an exercise book, you see, you do even have a curriculum. So you have to go to the classroom with all of those documents, and when you have them, later the student teacher should have them when s/he will go to teach, because it's like a culture. They take it as a culture and even when you visit them during the period of internship, you will realize that they have picked it up, when you visit her/ him, you will find her/him having all of those documents; s/he should have all of them. You see, this is the good example s/he got!! From where? From her/his teacher educator. When you go in the classroom to teach without having all those documents, you understand that student teacher will miss what they were supposed to learn from you and s/he will take it to her/his home school. You see the teacher educator would be serving as good example for those student teachers..." (Magaju,58-70).

For the participant, Magaju, regularity of completing pedagogical documents indirectly teach student teachers how to prepare for their own prospective teaching practice. This is emphasized by other participants who believe that, though the requirement is tacit for student teachers, having pedagogical documents serves as an exemplar practice for prospective teachers (Gasogi: 42-49; Kiyovu: 112-114 \& Gicumbi:59-62). This shows that participants believe that administrative preparation of teaching should be tacitly modelled as a training strategy of prospective teachers.

\section{Modelling through unreflected practice}

Participants view role modelling in three perspectives: exemplar practice through knowledge of the teacher educator, teaching methods and management of students. First, it is believed that the teacher educator should show mastery of content as a way of letting student teachers learn that a teacher should master the content (Kiyovu:182-183). Second, interviewees think that role modelling takes place when learner-centred methods are used. This means that once student teachers are taught through learner-centered teaching, they are likely to use the same method when they teach (Rayon:231-235). Unfortunately, one interviewee believes that such active methods should be used only because they are recommended as best methods of teaching by education 
policy makers (Zebra:411-412). For Zebra, believing in role modelling through active methods seems to be related to public education policy, not as a personalized view. Third, participants think that modelling practice is seen via the management of students, especially those with diverse learning needs (Police:72-78; Rayon:128-132) and students with learning difficulties should be given extra-support from teacher educators (Musanze: 411-413). By this, participants say student teachers would implicitly learn how to manage students with diverse learning needs. Another aspect as added by Kiyovu is punctuality. By being punctual, a teacher educator tacitly trains prospective teachers to learn punctuality (120-121).

\subsubsection{Implicit exemplar behavior}

In addition to modelling through their teaching practices, participants think that this has to be visible in terms of teacher educators' behavior within teacher training institution and the society.

\section{Inside teacher training}

Participants in the study at hand understand that role modelling should be shown in terms of teacher educators' conduct, especially socially acceptable behavior. For example, one participant expressed his thought about role modelling through dressing.

“...you have to go to school being well dressed, right? Good dressing up doesn't mean new clothes, that is, you wear clean clothes and clothes that don't distract children, so that you may serve as good example for children., For example a male teacher who may wear pants down to the waist, what kind of example would you serve to your students? What s/he observes from you, s/he will take it to where s/he will be teaching ..." (Magaju: 49$54)$.

In the views of Magaju and others, teacher educators should take care of the choice of clothes they should put on when they are training teachers (Gasogi: 163-164 \& Mukura: 447-449). Another aspect is modelling through collaboration and relationship with fellow teacher educators.

This goes together with being a role model. This is because when you teach student teachers and tell that them they have to collaborate but they do not see you collaborating with your colleagues, they will realize that what you tell them might be liars you see normally, what is observed is more easily understood than what someone hears. This is because what is 
done and observed is the reality, what is not practiced is not the reality (266-270) ...... eeh if for example is the one who is not good relationship with her/his co-workers, who is always in conflict with others, you see in whatever circumstances, student teachers will know it and once it is known, it negatively impacts on her/his teaching as well as learning of her/ his student teachers..." (Kigali: 140-144).

As expressed by Kigali and emphasized by Kirehe:180-182 \& Mukura:364-365, teacher training is closely linked to teacher educators' behaviors inside as well as outside classroom. For them, nurturing good relationships and collaboration with fellow teacher educators as well as institution leadership is an integral part of teacher training process as far as role modelling is concerned.

\section{Role modelling in the society}

For participating teacher educators, role modelling inside teacher training alone is not sufficient. They believe that the teachers' life in society should serve role modelling. For example, Kirehe thinks that student teachers inquire about and watches teacher educators' life in the society and therefore the latter should nurture good relationship with neighbors. This is reinforced by Kigali who believes that teacher educators' way of life and teacher educators' behaviour in the society are part of teaching teachers (139-140). Kirehe reinforces this:

"...even outside the school ... they learn from them may be the good values they see with them. When it is not the case, they start to despise teacher educator's advice, saying, what is he/she talking about? Did he/she achieve anything in life? What benefit did he/she get out of what he/she teaches us? They may say; we used to meet him drunk! Or she does not behave. We see her in adultery affairs and so on... That is why teachers should pay attention to their behavior in the society so that they may not be bad role model to their students..." (163-169).

Similarly, participants believe that teacher educators should serve as role models for student teachers when they play the role of social agent of change. Kirehe expresses this as follows:

"...how does a teacher educator contribute to the transformation of the society outside school context, does s/he participate in population meeting like meetings aiming at sensitizing people about family planning? A teacher educator may facilitate such meetings by sharing her/his knowledge with the population or for the one who teaches the same content in classroom. How does s/he collaborate with health counselors? You see, this is 
their contribution outside. It should not only concern school related activities, you see, this will reach student teachers who will later understand that it is necessary to participate in the process of transformation of the society in which they live outside school context..." (Kirehe: 203-211)

This implies that teacher educators are thought to take part in productive activities of social transformation using knowledge that they dispense in the classroom and serving as role models to student teachers who will likely participate in similar social activities where they will serve as teachers.

\section{Discussion}

The findings of the study show that participating teacher educators are aware of the importance of role modelling in the process of teacher training through implicit exemplary practice and behavior within and outside the training institution. On the one hand, participants believe that they should serve as role models through fulfilling the formalities of preparation of administratively required pedagogical documents. Additionally, role modelling is thought to be seen through teaching practice, materialized through mastery of content, use of learner-centered teaching methods, classroom management, especially for students with diverse learning needs, and providing extrasupport for those with learning difficulties. Participants likewise believe that role modelling should be shown through behavior, especially socially acceptable dressing and good conduct within and outside the training institution, and good relationships and collaboration with fellow teachers. Additionally, teacher educators serve as role models for student teachers in terms of being agents of social transformation. The results show that participants think that modelling should be done implicitly. This means that student teachers observe and learn from teacher educators' practices and behavior.

\subsection{Teacher educators' understanding of role modelling}

The results of the study show that participating teacher educators are aware of the significance of role modelling as a tool for preparing prospective teachers. Though findings of the current study and those of existing ones (Lunenburg, Korthagen \& Swennen, 2007 \& Loughran \& Berry, 2005) both reveal teacher educators' awareness that they should be role models to their student teachers, the orientation of the current study is different. While previous studies emphasize and encourage explicit modelling (Lunenburg et al, 2007 \& Wubbels, Korthagen \& Broekman, 1997), the findings 
of this study show that participating teacher educators' beliefs about modelling are oriented towards implicit modelling. Participating teacher educators believe that it is enough for student teachers to learn from observation. This means that reflections over reasons behind teaching practice are missing in their beliefs about role modelling in teacher education. The findings are rooted in Bandura's observational learning theory which assumes teaching and learning occur through observation. However, observation learning has its limitations especially when observer or student remains passive and this applies in the context of teacher education.

\subsection{Significance of implicit role modelling in Rwandan context}

The findings of implicit exemplarity could be interpreted contextually in three perspectives. First, the findings may be explained by the persistence of teacher-dominated pedagogy in teaching and teacher education in Rwanda (Otara, Uworwabayeho, Nzabalirwa \& Kayisenga \& 2019; Kuilen, Altinyelken Voogt \& Nzabalirwa, 2019; Iwakuni, 2017 \& Sibomana, 2014). Both with implicit exemplary practices and teacher-dominated pedagogy, the student is a passive observer who is expected to learn from the expert teacher. This implies that reflections on role modelling as a tool for quality teacher education should be undertaken in the framework of other aspects of studentcentered methods in the context. Second, implicit exemplary behavior may be related to the social life and role of a teacher in the society. On the one hand, beliefs of teacher educators regarding role modelling outside the school context may be explained by the fact that the social and the professional seem to be symbiotic in Rwanda. A teacher, on the other hand, is seen as an agent for social and economic transformation. A teacher is seen as a role model in the social life outside school. This may explain why teacher educators think that they should be role models for student teachers to implicitly prepare them for such role. Third, the implicit modelling of teacher educators may be explained by the educational and professional background of teacher educators. The latter are either trained as teachers or subject specialists and do not have either pre- nor in-service training on teacher professionalization. It seems that their knowledge of explicit modelling in the context of teacher education is very little.

\subsection{Implicit exemplarity and teacher education}

The findings of the study at hand show that participating teacher educators have implicit exemplary practice and behavior-oriented beliefs about role modelling. Given that beliefs are likely to influence practice (Martinez et al., 2017\&Voss et al., 2013), this may show that explicit modelling 
might be unknown by participating teacher educators as far as quality teacher education is concerned. However, research has shown that implicit modelling is ineffective, especially by leaving reflections behind teaching practices to remain as hidden choices and practices to student teachers, thereby hindering their learning to teach (Lunenburg, Korthagen \& Swennen, 2007:590). When studies assert that explicit role modelling is important for quality teacher education but the reflections of teacher educators in the context of teacher education in Rwanda do not show this awareness, then we have a gap that requires to be reflected upon.

While role modelling is discused in previous studies (Lunenberg, Korthagen \& Swennen, 2007; Loughran, 2006 \& Loughran \& Berry, 2005) in terms of practice, the present study reveals context-oriented beliefs as behavior (outside classroom and in the society). In line with previous studies showing that beliefs are context-bound (Martinez et al., 2017), the findings of this study are likewise context-oriented as far as beliefs of teacher educators about role modelling are concerned. This implies that the quality of teacher education is likely to be reflected upon contextually.

\section{Conclusion and perspectives}

The findings of this study reveal that participating teacher educators believe that role modelling is an important component in the process of teaching teachers. Moreover, results show that participants' understanding of role modelling is about implicit exemplar practices and behavior. Study participants think that teaching teachers is more than providing knowledge but also includes serving as good examples in both teaching practice and behavior at training institutions as well as within the larger society. Using the lenses of social cognitive theory (Bandura, 1968) and implicit modelling, especially in the context of their potentials and limitations, the findings of this study suggest that both sides of modelling should be included in in-service training of teacher educators in Rwanda. Further research should investigate implicit role modelling and learning experiences of student teachers; investigating specially how and what student teachers learn through teacher educators' implicit role modelling in the course of teacher education.

I thank the Bamberg Graduate School of Social Sciences (BAGSS) at Otto-Friedrich University of Bamberg/Germany, the German Academic Exchange Service (DAAD) and Prof. Dr. Annette

Scheunpflug for the support of this study. 


\section{References}

Bandura, A. (1971). Social learning theory. New York: General Learning Press.

Bandura, A. (1986). Social foundations of thought and action. Upper Saddle River, NJ: Prentice Hall.

Bandura, A. (2001). Social Cognitive Theory: An Agentic Perspective. Annual Review Psychology, 52 (1), 1-26. DOI: 10.1146/annurev.psych.52.1.1

Baumert, J. \& Kunter, M. (2013). The COACTIV model of teachers' professional competence. In M. Kunter et al (Eds), Cognitive activation in the Mathematics classroom and professional competence of teachers: Results from the COACTIV Project. New York and London: Springer.

Blume, R. (1971). Humanizing teacher education. The Phi Delta Kappan, 52(7), 411-415.

Chernikova, O. (2018). What makes observational learning in teacher education effective? (Doctoral dissertation, lmu). Munich Center of the Learning Sciences at LudwigMaximilians-Universität, München.

Creswell, J.W. (2014). Research design: Qualitative, quantitative, mixed methods approaches ${ }^{4 \text { th }}$ Ed.). Los Angeles, London, New Delhi, Singapore, Washington, DC: SAGE.

European Commission (2017). Preparing teachers for diversity: The role of initial teacher education. Luxembourg: European Union.

Hansen, R. E. (2000). The Role of Experience in Learning: Giving Meaning and Authenticity to the Learning Process in Schools. Journal of Technology Education, 11(2), 23-32.

Hattie, J. (2012). Visible learning for teachers: Maximizing impact on learning. London and New York: Rutledge.

HEC (2015). A tracer study of graduates from Higher Learning Institutions and Employers' satisfaction of graduates' competences. Kigali, Rwanda [(A study carried by Rwanda Association of Local Government Authorities (RALGA)]. 
Iwakuni, S. (2017). "Impact of initial teacher education for prospective lower secondary school teachers in Rwanda." Teaching and Teacher Education 67 (2017): 538-549.

Korthagen, F., Loughran, J., \& Russell, T. (2006). Developing fundamental principles for teacher education programs and practices. Teaching and teacher education, 22(8), 1020-1041.

Korthagen, F.A.J., Kessels, J., Koster, B., Lagerwerf, B. \& Wubbels, T. (2001). Linking practice and theory: The pedagogy of realistic teacher education. Mahwah: Lawrence Erlbaum Associates.

Lane, R., McMaster, H., Adnum, J., \& Cavanagh, M. (2014). Quality reflective practice in teacher education: A journey towards shared understanding. Reflective Practice, 15(4), 481-494.

Loughran, J. (1996). Developing reflective practice: Learning about teaching and learning through modelling. London/Washington, DC: Falmer Press.

Loughran, J. (2006). Developing a pedagogy of teacher education: Understanding teaching \& learning about teaching. New York: Routledge.

Loughran, J., \& Berry, A. (2005). Modelling by teacher educators. Teaching and teacher education, 21(2), 193-203.

Lunenberg, M., Dengerink, J., \& Korthagen, F. (2014). The professional teacher educator: Roles, behaviour, and professional development of teacher educators. Rotterdam / Boston / Taipei: SENSE PUBLISHERS.

Lunenberg, M., Korthagen, F., \& Swennen, A. (2007). The teacher educator as a role model. Teaching and teacher education, 23(5), 586-601.

MacMillan, J. \& Schumacher, S. (2014). Research in education: Evidence-based inquiry (7th Ed.). Harlow: Pearson Education Limited.

Martinez, D. C., Castro, P. J. \& Vytreilova, P. (2017). A Review of research on teachers' subjective theories: Contributions to the study of teacher education. Psychology and Education, An Interdisciplinary Journal, 54 (3), 1-22.

Mason, J. (2018). Qualitative researching (3rd Ed.). Los Angeles, London, New Delhi, Singapore, Washington DC, Melbourne: SAGE. 
Mathew, P., Mathew, P., \& Peechattu, P. J. (2017). Reflective practices: A means to teacher development. Asia Pacific Journal of Contemporary Education and Communication Technology, 3(1), 126-131.

Mayring, P. (2014). Qualitative content analysis: theoretical foundation, basic procedures and software solution. URN: http://nbn-resolving.de/urn:nbn:de:0168-ssoar-395173.

MINEDUC (2018). Education Sector Strategic Plan 2017/2018-2023/2024. Kigali, Rwanda.

MINEDUC (2020). 2019 Education Statistical yearbook. Kigali, Rwanda.

MINEDUC/REB (2015). Competence-based curriculum: Curriculum Framework pre-primary to upper secondary. Kigali, Rwanda.

MINEDUC/REB (2019). Curriculum framework for Teacher Training Colleges. Kigali, Rwanda.

Mugisha, I. S. (2010). Assessment and study strategies: A study among Rwandan students in higher education (Doctoral dissertation, Linköping University Electronic Press).

Munby, H., Russell, T., \& Martin, A. K. (2001). Teachers’ Knowledge and How It Develops. In V. Richardson (Ed.), Handbook of Research on Teaching (pp. 877-904). Washing-ton, DC: AERA.

Nilsen,T., Gustafsson, J.E. \& Blömeke, S.(2016). Conceptual Framework and Methodology of This Report. In T. Nilsen \& J.E. Gustafsson (Eds) Teacher Quality, Instructional Quality and Student Outcomes: Relationships across Countries, Cohorts and Time. International Association for the Evaluation of Educational Achievement (IEA) \& Springer Open.

Otara, A., Uworwabayeho, A., Nzabalirwa, W., \& Kayisenga, B. (2019). From ambition to practice: An Analysis of Teachers' Attitude Toward Learner-Centered Pedagogy in Public Primary Schools in Rwanda. SAGE Open, 9(1), 2158244018823467.

Philpott, C. (2014). A pedagogy for initial teacher education in England. Teacher Education Advancement Network Journal, 6(3), 4-16.

Russell, T., \& McPherson, S. (2001, May). Indicators of success in teacher education. In Communication présentée à Pan-Canadian Education Research Agenda Symposium Teacher Education/Educator Training: Current Trends and Future Directions, Université 
Laval, Québec. Repéré à http://www. cesc. ca/pceradocs/2001/papers/01Russell_McPherson_e.pdf.

Savin-Baden, M. \& Major, C. H. (2013). Qualitative research: The essential guide to theory and practice. London \& New York: Routledge.

Sibomana, E. (2014). The role of distance education materials in addressing the professional development needs of high school English teachers in Rwanda. Unpublished PhD Thesis, University of the Witwatersrand, Johannesburg, South Africa.

Silverman, D. (2014). Interpreting qualitative data (4th Ed.). Los Angeles, London, New Delhi, Singapore \& Washington DC.: SAGE.

Swennen, A. \& White, E. (2021). Being a teacher educator: Research-informed methods for improving practice. London \& New York: Routledge.

Thornburg, R. \& Charmaz, K. (2014). Grounded theory and theoretical coding. In U. Flick (Ed.), The handbook of qualitative analysis (pp.170-183). London, New Delhi, Thousand Oaks, Singapore: SAGE.

UNESCO (2004). Education for All. The Quality Imperative. Global Monitoring report. Paris: UNESCO.

UNESCO (2014). Education for All. Teaching and Learning: Achieving quality for all. Global Monitoring report. Paris: UNESCO.

UNESCO (2015). Education for All: Achievements and challenges. Global monitoring Report. Paris: UNESCO.

UNESCO (2017). Education for Sustainable Development Goals. Paris: Author.

van de Kuilen, H. S., Altinyelken, H. K., Voogt, J. M., \& Nzabalirwa, W. (2019). Policy adoption of learner-centred pedagogy in Rwanda: A case study of its rationale and transfer mechanisms. International Journal of Educational Development, 67, 64-72.

Vavrus, F., Thomas, M. \& Bartlett, L. (2011). Ensuring quality by attending to inquiry: Learnercentred pedagogy in Sub-Saharan Africa. Fundamental of Teacher Education Development 4. Addis Ababa: UNESCO/ IICBA. 
Villegas-Reimers, E. (2003). Teacher professional development: An international literature review. Paris: UNESCO/IIEP.

Voss, T., Kleickmann, T., Kunter, M. \& Hachfeld, A. (2013). Mathematics teachers' beliefs. In M. Kunter et al. (Eds), Cognitive activation in the Mathematics classroom and professional competence of teachers: Results from the COACTIV Project. New York and London: Springer.

World Bank (2011). Rwanda education country status report. Toward quality enhancement and achievement of universal nine-year basic education: An education system in transition; a nation in transition. Washington: World Bank.

World Bank (2018). Learning to realize education promise. Washington, DC: Author.

Wubbels, T., Korthagen, F., \& Broekman, H. (1997). Preparing teachers for realistic mathematics education. Educational studies in mathematics, 32(1), 1-28. 